транспортирование, ношение или использование оружия, основных частей огнестрельного оружия и патронов к оружию, в том числе пневматического оружия с дульной энергией ниже 7,5 Дж и калибра 4,5 мм и патронов к нему, лицом, ранее подвергнутым административному наказанию».

3. В-третьих, учитывая характер возможных повреждений, общественную опасность и латентность преступлений в сфере незаконного оборота оружия, целесообразным, на наш взгляд, стало бы введение новой нормы в УК РФ, закрепляющей незаконные изготовление, приобретение, продажу, передачу, сбыт, хранение, перевозку, транспортирование, ношение или использование пневматического оружия с дульной энергией ниже 7,5 Дж и калибра 4,5 мм, основных частей и патронов к нему. В качестве квалифицирующего и особо квалифицирующего составов следовало бы указать размер тяжести причинённого посредством указанных выше действий вреда здоровью.

$$
* * *
$$

1. Уголовный кодекс Российской Федерации от 13.06.1996 № 63-Ф3 (ред. от 11.06.2021) // Собрание законодательства РФ, 17.06.1996, № 25, ст. 2954.

2. Постановление Конституционного Суда РФ от 10.02.2017 № 2-П «По делу о проверке конституционности положений статьи 212.1 Уголовного кодекса Российской Федерации в связи с жалобой гражданина И.И. Дадина» // Собрание законодательства РФ, 27.02.2017, № 9, ст. 1422.

3. Ямашева Е.В. К вопросу о восстановлении института административной преюдиции в уголовном законе России // Журнал российского права. 2009. № 10. - С. 71.

4. Безверхов А.Г. Возвращение «административной преюдиции» в уголовное законодательство России // Российская юстиция. 2012. № 1. - С. 50.

5. Бавсун М.В., Бавсун И.Г., Тихон И.А. Административная преюдиция и перспективы ее применения на современном этапе // Административное право и процесс, 2008, № 6. - С. 4.

6. Послание Президента РФ Федеральному Собранию от 12.11.2009 «Послание Президента РФ Дмитрия Медведева Федеральному Собранию Российской Федерации» // Российская газета, № 214, 13.11.2009.

7. Федеральный закон от 13.12.1996 № 150-Ф3 (ред. от 08.12.2020) «Об оружии» // Собрание законодательства РФ, 16.12.1996, № 51, ст. 5681.

8. Приказ Росгвардии от 18.08.2017 № 359 «Об утверждении Административного регламента Федеральной службы войск национальной гвардии Российской Федерации по предоставлению государственной услуги по выдаче гражданину Российской Федерации лицензии на приобретение спортивного или охотничьего огнестрельного гладкоствольного длинноствольного оружия, охотничьего пневматического оружия и спортивного пневматического оружия с дульной энергией свыше 7,5 Дж и патронов к нему» (зарегистрировано в Минюсте России 20.09.2017 № 48256) // Российская газета, № 223, 04.10.2017.

9. Козаченко И.Н. Классификация пневмострельных повреждений // Судебно-медицинская экспертиза. 2016. 59 (4). - C. 12.

10. Кодекс Российской Федерации об административных правонарушениях от 30.12.2001 № 195-Ф3 (ред. От 28.06.2021) // Собрание законодательства РФ, 07.01.2002, № 1 (ч. 1), ст. 1.

11. Приказ Минздравсоцразвития РФ от 24.04.2008 № 194н (ред. от 18.01.2012) «Об утверждении Медицинских критериев определения степени тяжести вреда, причинённого здоровью человека» (зарегистрировано в Минюсте РФ 13.08.2008 № 12118) // Российская газета, № 188, 05.09.2008.

12. Бурлаченко М.А. Проблемы субъекта преступлений в сфере незаконного оборота оружия / Научный журнал «Эпомен», № 55, 2021. - С. 84.

\title{
Ковальская В.В., Штыков В.П. \\ Проблемные аспекты регулирования венчурного инвестирования в России. Намечающиеся тенденции в обеспечении правовой базы
}

ФГАОУ ВО «Дальневосточный федеральный университет» (Россия, Владивосток)

doi: 10.18411/trnio-09-2021-78

Научный руководитель: Штыков В.П.

\section{Аннотация}

В данной статье анализируется действующее законодательство в области правового регулирования венчурной деятельности. Цель данного исследования заключается в выявлении актуальных проблем и пробелов в законодательстве. В статье также приведён 
обзор последних изменений правовой базы в исследуемой области, чем обоснована научная новизна исследования. Также сделаны выводы относительно возможности урегулирования венчурного инвестирования в рамках отдельного законодательного акта, выявлены некоторые особенности венчурной деятельности, которые требуют рассмотрения данного вида инвестирования обособлено в рамках существующей специфики.

Ключевые слова: венчурное инвестирование, регулирование инвестиций, венчурный бизнес, краудфандинг, инвестиционная деятельность, правовое регулирование, законодательство, стартап, венчурный инвестиционный договор, инновационная деятельность.

\section{Abstract}

The article examines the current legislation in the field of venture investment. The purpose of this study is to identify actual problems and gaps in legislation. The article provides an overview of the latest changes in the legal framework in the field of the research. As the result, conclusions have been drawn about the possibility of regulation venture investment within the separate legislative act, some features of venture activity were determined which require consideration of this type of investment separately, taking into account the specifics.

Keywords: venture investment, regulation of investment, business venture, crowdfunding, investment activity, legal regulation, legislation, startup, venture investment agreement, innovation activity.

Инновационная деятельность в России главным образом регулируется законом «Об инвестиционной деятельности в Российской Федерации, осуществляемой в форме капитальных вложений» № 39-Ф3 от 25.02.1999 года [7]. Данный закон не просто определяет основы инновационной деятельности, но устанавливает гарантии равной защиты прав и интересов субъектов инновационной деятельности. Отдельным видом инвестиционной деятельности являются вложения в реализацию инновационных проектов, либо же вложения в так называемые «стартапы», компании, которые являются высокорисковыми, но при этом характеризуются высоким потенциалом роста. В современных условиях особую важность приобретают инновационные решения, которые позволяют развиваться и выживать компаниям, переживающим кризисы, а также страдающим от последствий пандемии. Более того, в условиях кризиса, высокотехнологичные проекты становятся возможностью для преодоления экономического упадка. Примером этому могут послужить различные онлайнсервисы для обучения и совершения покупок. Но стоит учесть, что экономические, политические и инфраструктурные проблемы создают более высокий риск для тех, кто осуществляет финансирование таких проектов и компаний. Именно поэтому особую важность приобретает выбор приемлемых и надежных механизмов регулирования венчурной деятельности, которые помогли бы защитить инвесторов от неоправданных рисков и обеспечили бы определённые гарантии, что в дальнейшем бы обеспечило более устойчивый приток инвестиций в инновационный сектор экономики.

В связи с этим, объектом данного исследования являются существующие нормативноправовые акты в области регулирования инвестиционной деятельности, а предметом исследования является регулирование высокорисковых вложений. Более конкретно в работе будут рассмотрены последние изменения в законодательстве, которые касаются финансирования венчурного бизнеса, а также выявлены проблемы, которые связаны с пробелами в законодательстве и сложностью объектов регулирования.

В первую очередь, стоит разобраться с определением понятия «венчурных инвестиций» в российском законодательстве. В России не существует нормативно-правового акта, который бы напрямую регулировал венчурную деятельность, как, например, в Индии или Венгрии, а в основных законодательных актах, в том числе в законе «Об инвестиционной деятельности в Российской Федерации, осуществляемой в форме капитальных вложений» № 39-Ф3 от 25.02.1999 и в законе «Об инвестиционных фондах» № 
156-Ф3 от 29.11.2001 данное понятие не определено однозначно [3]. В юридической литературе, в том числе в работе Беседина А. А., даётся понятие «венчурного инвестиционного договора», представляющего собой имеющее срочный характер соглашение между инвестором и получателем инвестиций, по которому венчурные инвестиции предоставляются в обмен на долю в уставном капитале компании-получателя [1]. Здесь же стоит упомянуть относительно недавно принятый закон «О внесении изменений в Федеральный закон «О науке и государственной научно-технической политике» от 31.07.2020 № 309-Ф3. В данном законе даётся определение термина «инновационный проект», а также определяется понятие «венчурного инвестирования инновационного проекта» [6]. Таким образом, предпринимаются попытки закрепить однозначное определение как самой венчурной деятельности, так и высокорискового инвестирования. В том числе, с 2009 года предпринимаются попытки создать закон «О венчурной деятельности», но на данный момент существуют только наработки, данная инициатива не увенчалась успехом.

В целом, говоря о источниках регулирования инвестиционной деятельности в Российской Федерации, важно отметить, что инвестиционное законодательство содержит нормы как частного, так и публичного права - это связано в том числе с большим набором участников данного вида правоотношений, включающих изобретателей, предпринимателей и специализированные организации, поэтому закон, который бы напрямую регулировал венчурную деятельность, должен иметь сложный комплексный характер.

Здесь же стоит отметить недостаток юридических исследований в области инвестиций. Зачастую категории «инвестирование» и «инвестиции» принято считать именно экономическими, хотя фактически они наделены правовым содержанием и требуют законодательного урегулирования [8].

Не менее сложными являются высокорисковые инвестиционные отношения. Стоит учитывать, что зачастую предметом данных отношений являются не только договоры между инвестором и компанией, но и отношения по поводу оборота ценных бумаг и финансовых инструментов. Венчурное инвестирование может осуществляться в различных формах, в том числе: через покупку акций компании, путём предоставления займов, через взаимодействие с инвестиционным фондом, посредством приобретения материалов, оборудования, через коммерческие кредиты, либо же используя комбинацию перечисленных форм. Соответственно - создаются различные типы правовых отношений. Более того, объектом инвестирования могут выступать нематериальные активы, которые не могут выступать залогом, который послужил бы гарантией для инвестора [9].

Для того, чтобы как-то защитить интересы инвестора, а также дать возможность заёмщику реализовывать проект без постороннего участия, 15 июня 2020 г. в Государственную Думу РФ был внесён законопроект № 972589-7. Данный проект вносит изменения в отдельные акты в части конвертируемого займа. Фактически - это правовой механизм, который поможет сбалансировать интересы инвестора и заёмщика, особенно что касается инвестиций в высокотехнологичные проекты, где существует высокий риск. Данная практика давно используется за рубежом, причём эта модель достаточно популярна среди мировых венчурных фондов.

Сам договор конвертируемого займа предполагает, что инвестор предоставит финансирование на первом этапе реализации проекта, а получатель займа должен будет его вернуть в определённый срок с процентами, либо же предоставить инвестору долю в компании. Выходит, что по данному договору у инвестора есть возможность сохранить за собой право на возврат займа, не приобретая долю в компании, которая может оказаться убыточной. Заёмщик же получает возможность не привлекать инвестора к управлению компанией, поскольку тот будет являться кредитором, а не владельцем доли компании [5].

Данный проект был принят Государственной Думой 08.06.2021 г. Можно утверждать, что российское законодательство всё ещё находится на этапе формирования законодательной базы для успешного финансирования венчурной деятельности, но опять же, намечаются 
положительные тенденции в вопросах правового регулирования, более того, если учесть опыт зарубежных стран, то можно сказать, что отсутствие законодательного акта, напрямую регулирующего данный вид деятельность, не всегда является проблемой.

В качестве отдельного вопроса целесообразно рассмотреть участие государства в венчурном финансировании. Например, финансирование прикладной науки путём заключения контрактов с венчурными фирмами, либо же создание технопарков. В целом фирмам это выгодно, поскольку, объединившись вокруг такого технопарка, они получают налоговые льготы. В целом, что касается налоговых льгот, то полный перечень льгот для инвесторов, инвестирующих в стартапы, ещё находится в разработке по поручению Президента. На данный момент действуют льготы при осуществлении расходов на НИОКР, применение инвестиционного налогового вычета, применение специального коэффициента для основных средств, используемых для таких проектов, применение повышенного коэффициента к норме амортизации основного оборудования (перечень определён Правительством РФ). Пока этот вопрос ещё прорабатывается [4].

Показательным является инцидент, произошедший во время встречи Президента с лидерами технологических проектов в 2019 году. Во время этой встречи было высказано опасение, что действующая регламентация использования бюджетных денег при финансировании технологических проектов, в случае неудач проектов может обернуться уголовной ответственностью. В связи с этим было Президентом было поручено создать новый законопроект об установлении допустимого уровня риска при использовании бюджетных средств [10].

Закон также был принят в июле 2020 года. Сам документ включает в себя общие положения об основных критериях оценки рисков при реализации высокотехнологичных и рискованных проектов. Таким образом, сделана попытка устранить «зарегулированность» использования бюджетных денежных средств, уменьшив вероятность неудачи при реализации за счёт оценки по критериям.

Отдельным видом венчурного финансирования является краудфандинг. Само определение краудфандинга в законодательстве не определено, но принято считать, что краудфандинг представляет собой коллективное сотрудничество лиц, добровольно направляющих средства на поддержание проектов, которые публикуются на цифровых платформах. Иногда краудфандинг принято выделять как отдельный вид инвестирования и противопоставлять венчурному инвестированию, но фактически через краудфандинг также осуществляется финансирование высокорисковых проектов, но с определёнными особенностями.

Длительное время существовали законодательные пробелы в области регулирования данного вида инвестирования, но с 1 января 2020 года вступил в силу закон «О привлечении инвестиций с использованием инвестиционных платформ и о внесении изменений в отдельные законодательные акты Российской Федерации» № 259-Ф3 от 02.08.2019 г. В проекте была осуществлена попытка законодательного закрепления термина «краудфандинг», но потом данная инициатива была отклонена в процессе согласования. В целом закон был разработан в целях защиты инвесторов от мошенников. В законе определён перечень требований к получателям денежных средств: от ограничения сумм, привлекаемых одним лицом в определённый срок, до требований о предоставлении бухгалтерской отчётности [2].

В соответствии с Указом Президента РФ от 07.05.2018 № 204 «О национальных целях и стратегических задачах Российской Федерации на период до 2024 года» одной из целей, которая должна быть достигнута в указанный период, является «ускорение технологического развития РФ», это можно обеспечить именно за счёт венчурного финансирования, этот инструмент является ключевым для разработки инновационных проектов. Безусловно, принятые изменения в законодательство можно назвать целесообразными, но оценка результатов внедрения пока не представляется возможной, поскольку изменения вступили в силу относительно недавно. 
Венчурный бизнес является крайне изменчивым, как и особенности финансирования такого бизнеса. Поэтому требуется постоянный контроль и обновление законодательной базы. Но только обеспечив равновесную защиту интересов сторон высокорисковых инвестиционных отношений, можно ускорить развитие данной области в положительном ключе.

$$
* * *
$$

1. Беседин, А. А. Термин «венчурный» в гражданском законодательстве России / А. А. Беседин // Современные гуманитарные исследования. 2015. № 1. С. 60-62.

2. Габов, А. В. Краудфандинг: законодательное оформление web-модели финансирования в контексте правовой доктрины и зарубежного опыта / А. В. Габов, И. А. Хаванова // Вестник Пермского университета. Юридические науки. 2020. Вып. 47. С. 28-44.

3. Жданова, О. А. Общая оценка правового поля венчурной деятельности в России / О. А. Жданова, К. В. Миляев, А. А. Кушнаренко // Universum: экономика и юриспруденция: электрон. научн. журн. 2016. № 9 (30). URL: https://7universum.com/ru/economy/archive/item/3542 (дата обращения: 12.06.2021).

4. Косьянов, В. А. Проблемы развития венчурного финансирования в России: институциональные аспекты / В. А. Косьянов, В. В. Куликов, Е. Л. Гольдман // Экономика: вчера, сегодня, завтра. 2021. №1-1. С. 9-16.

5. О внесении изменений в отдельные законодательные акты Российской Федерации (в части конвертируемого займа) Законопроект № 972589-7 // [Электронный ресурc] URL: https://sozd.duma.gov.ru/bill/972589-7

6. О внесении изменений в Федеральный закон «О науке и государственной научно-технической политике» Федер. закон от 31 июля 2020 г. № 309-Ф3. Доступ из СПС «КонсультантПлюс». - Текст : электронный.

7. Об инвестиционной деятельности в Российской федерации, осуществляемой в форме капитальных вложений: Федер. закон от 25 февраля 1999 г. № 39-Ф3 ( ред. от 8 декабря 2020 г.). Доступ из СПС «КонсультантПлюс». - Текст : электронный.

8. Свечников, В. А. Актуальные вопросы правового регулирования инвестиционной деятельности в Российской Федерации / В. А. Свечников // Экономика. Право. Общество. 2019. № 1. С. $82-87$.

9. Собченко, Н.В. Особенности юридического оформления договоров между инвесторами и венчурными компаниями / Н. В. Собченко // Политематический сетевой электронный научный журнал Кубанского государственного аграрного университета. 2014. № 95. С. 886-897.

10. Тажудинова, Д. А. Об особенностях инвестиций в ИТ - сектор / Д. А. Тажудинова, Д. С. Аджаматова // Инновации и инвестиции как драйверы социального и экономического развития: сборник статей Международной научно-практической конференции. 2020. С. 26-28.

\title{
Лобовской А.П. \\ Проблемы гражданско-правовой ответственности по договору морской перевозки грузов морским транспортом
}

\author{
Дальневосточный федеральный университет \\ (Россия, Владивосток)
}

doi: 10.18411/trnio-09-2021-79

Научный руководитель: Штыков В.П.

\section{Аннотация}

Целью исследования является анализ действующего законодательства и правоприменительной практики для последующего совершенствования законодательства путем формирования концепций и идей по их разрешению, а также с целью последующих научных дискуссий по данной теме, а также пробелы в законодательстве, в том числе несоответствие действующей правоприменительной практики нынешнему законодательству. Так, в работе рассматриваются вопросы развития гражданского законодательства в сфере морской перевозки грузов. Научная новизна исследования основана на изучении актуальных проблем нормативного регулирования и правоприменительной практики. В результате формируются пути решения текущих проблем, выдвигаются теории совершенствования действующего законодательства Российской Федерации.

Ключевые слова: морская перевозка грузов, ответственность перевозчика, договор морской перевозки грузов, принцип вины. 